\title{
Measurement of Visitor's Satisfaction Through Importance Performance Analysis (IPA) Method About Servicescape
}

\author{
Pasaribu, Waryono, Ronaldi Saputra \\ Tourism Department \\ Universitas Negeri Padang \\ Padang, Indonesia \\ pasaribuary@gmail.com
}

\begin{abstract}
This research is motivated by the visitor's complaints about servicescape at the visitor Attraction of Ngalau Indah Cave in Payakumbuh city. The research objective was to determine the extent to which level of visitor satisfaction about servicescape Attraction in Ngalau Indah Cave in Payakumbuh, consisting of dimensions: ambient condition, spatial layout and functionality, sign, symbol, and artifacts. This research was a descriptive using quantitative data through survey method. The research population was the visitors who visited Ngalau Indah cave, Payakumbuh. Population of this research totaled 3,233 people. Sampling method used is non-probability sampling, with the kind of purposive sampling. The number of samples in this research amounted to 100 respondents. Data collection is done by distributing questionnaires using Likert scale that has been tested for validity and reliability. Furthermore, the data were analyzed through descriptive analysis Importance Performance Analysis (IPA) and categorizing the level of satisfaction based on four quadrant Cartesian diagram. The research concluded that the level of visitor satisfaction about services cape Attraction in Ngalau Indah Cave, Payakumbuh city in general as much as $35.72 \%$ of visitors expressed great satisfaction. While based on the dimensions services cape namely: 1) ambient condition, as many as $50 \%$ of visitors expressed great satisfaction. 2) spatial layout and functionality, as much as $\mathbf{4 0 \%}$ of visitors expressed great satisfaction. 3) sign, symbol, and artifacts, as much as $\mathbf{2 0 \%}$ of visitors expressed great satisfaction.
\end{abstract}

Keywords-Satisfaction level, Importance Performance Analysis (IPA) Servicescape, Tourism object

\section{INTRODUCTION}

West Sumatra is one of the provinces in Indonesia which has a natural beauty and unique culture as well as the potential to be developed into a tourist and cultural destination. Categories of this natural beauty can be an object landscape of beaches, mountain ranges, lakes, canyons and valleys or cultural objects. One of potential area to be developed into tourist destination in West Sumatra is Payakumbuh.

The tourist attractions in Payakumbuh are developed to make corrections, administered by the local government, then delivered and managed by the Department of Tourism, Youth and Sports of Payakumbuh city. One of famous attractions in
Payakumbuh is Ngalau Indah, because it is the most beautiful natural tourist attraction among other tourist attractions in Payakumbuh. This attraction is located on the slopes of the hills within $\pm 4 \mathrm{~km}$ from the city center of Payakumbuh, total area of 10 hectares with a height of 640 meters above sea level.

Servicescape / physical environment are all aspects of a service organization facilities include tangible attributes (tangible) where the service is delivered. Servicescape / underlying physical environment of a service consists of three dimensions: first: ambient condition, second: spatial layout and functionality, third: sign, symbol, and artifacts (Zeithaml and Bitner, and Grembler 2010: 12, Ruki, 2011)

Wakefield and Blodgett (1996), points of assessments that allowed in right services cape application are: satisfaction in services cape have a positive impact on the length of time will be spent in that place; satisfaction with the state of services cape can positively affect a person's desire to return to that place; and can get a lot more attention from visitors.

Based on observations at Ngalau Indah on February 17, 2016 and interviews with nine (9) of the visitors on February 17, 2016, researchers found a visitor complaints about services cape / physical environments of the tourist attraction of the Ngalau Indah. Here are complaints from visitors who have researchers grouped based on the dimensions of services cape by Zeithaml and Bitner.

First, the ambient condition: four visitors said that the attraction is not clean enough, because a lot of trash scattered, the smell of visitors urine, also the bat droppings that cause the odor, so that visitors feel uncomfortable during exploring the cave. The lighting is still minimal in the cave because of the lack of lighting, making visitors feel afraid to enter because of the dark. Name and ornaments of stone in a cave are not visible because the lighting is a little and rarely turned on. Based on interviews researchers, visitors said it was essential lighting for easy visibility through the cave.

Secondly, spatial layout and functionality: two of the visitors said that tourist attraction organizer does not provide safety equipment to explore the caves, and there is no sales of masks to browse through the cave. Third: sign, symbol, and 
artifacts: two of the visitors said that the lack of clarity of directions, and unavailability of a disaster evacuation route instructions in tourist attraction. Moreover, the unavailability of information boards of attraction profile of Ngalau Indah.

Same exposure was stated by the 2 (two) people of stall tenant along with 1 (one) parking attendant at the attraction on February 17, 2016, they stated that the attraction is not yet fully maintained and still under development. They said the lights in the cave are rarely turned on, and visitors often ask which way to enter the cave and where the information boards of the attraction is located. In addition, the kiosk renters also said visitors more deserted than eight years earlier.

Based on secondary data that researchers submitted from the exposure to the visitors, and the stall tenant, as well as a parking attendant who researchers interviewed, it can be seen that the growth of the visit's to Ngalau Indah Payakumbuh for 8 (eight) years tend to be unstable and the number of visits every year has not been able to balance out the number of visits in 2007, reaching 65624 visitors. In addition, $88.89 \%$ of the 9 (nine) visitors complain about services cape / physical environment that is supported by a statement from the tenants of kiosks and parking attendants, they said the same thing to the visitors, as a sign that it has not achieved what they expect, and yet known how far the level of visitor satisfaction about the services cape /physical environment in Ngalau Indah.

Visitors will be satisfied if what they experienced better than expected and would be disappointed if the opposite occurs. Satisfaction of every visitor has a different level. Indeed, the level of visitor satisfaction should be measured, known the factors, and needs to be improved by the company so that visitors are not disappointed, so the visitor loyalty will be formed. The satisfaction felt by the visitor will indirectly enhance the growth of traffic, because satisfied visitors who will be promoting a product or service to other people after what they feel equal to or more than what they expected.

Importance Performance Analysis (IPA) is one of the methods to measure and analyze the level of satisfaction, where this method has been generally accepted and used in various fields of study, because this method has easy to apply (Martinez, 2003). Extensively, Importance Performance Analysis (IPA) has been used in research hospitals and tourism (Goncalves, et al., 2014).

\section{METHOD}

This type of research carried out in this research is descriptive research quantitative data with survey method. The data obtained will be analyzed and interpreted in accordance with the objectives and research questions that have been raised.

In accordance with the problems of research and expert opinion on the above, the study aims to provide an overview, see, and reveals how the level of visitor satisfaction about services cape of the attraction in Ngalau Indah cave in Payakumbuh. The study design involves one (1) independent variables are represented by the letter $\mathrm{X}$, where $\mathrm{X}$ is the level of satisfaction of the visitors about services cape which terms of 3 (three) dimensions: ambient condition, spatial layout and functionality, sign, symbol, and artifacts. In this research will be measured and analyzed the level of visitor satisfaction with the method of Importance Performance. Analysis (IPA) on services cape Cave in Ngalau Indah cave, Payakumbuh.

Variabel in this research, there is one independent variable represented by $\mathrm{X}$. Where $\mathrm{X}$ is the level of visitor satisfaction about services cape about the attraction in Ngalau Indah Cave, Payakumbuh.

The research population was the visitors who visited attraction Ngalau Indah caves, Payakumbuh with population 3.223 visitors The method used in this research is a nonprobability sampling technique, the sampling method does not give an opportunity or equal opportunity for each element or population to be selected into the sample. While this type of non-probability sampling is purposive sampling, ie sampling technique with a certain considerations. In this study, the visitors were selected for the study was the visitors who are and have been to attraction and visit Ngalau Indah cave more than 1 time with the purpose of recreation or sightseeing. Then, the respondents of this research are 97 respondents.

The data collection technique used is the indirect communication through structured questionnaires. The questionnaire can be a statement and closed questions were given to respondents directly using Likert scale.

This research data analysis techniques using Importance Performance Analysis (IPA) or the analysis of the level of interest and performance, is used to answer the problem formulation regarding the extent to which the level of visitor satisfaction about servicescape in Ngalau Indah cave.

\section{RESULT}

Having obtained the degree of conformity, then the next step is finding the average of each attribute services cape, by dividing weight rating level of performance / execution and level of importance of each with the number of respondents 97. Next, it obtained an average of the average level of interest and level of performance / execution of services cape attributes. And, eventually gained the Cartesian diagram as described in fig.1. 


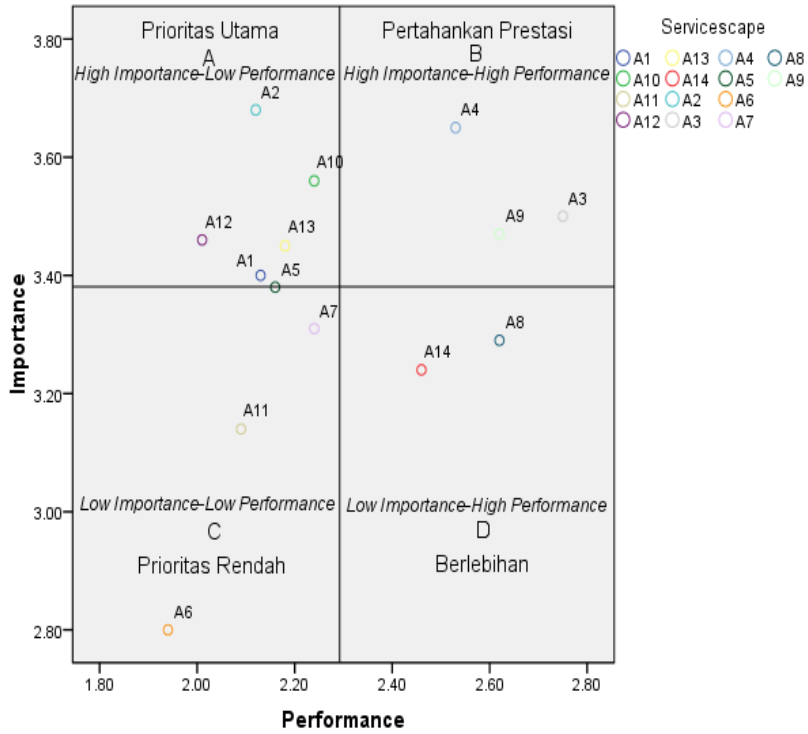

Fig. 1. Diagram Cartesian of Visitor Satisfaction Level Measurement About Servicescape In Ngalau Indah Caves

Based on the Cartesian diagram above, there are four quadrants with the following explanation:

a. Quadrant A (Priority)

A quadrant that indicates the attributes services cape considered very important visitors, but the management do not provide it, (High Importance-Performance Low) means visitors are not satisfied.

b. Quadrant B (Preserve Achievement)

A quadrant that indicates the attributes services cape considered very important visitors and managers already provide good, (High Importance-High Performance) can be interpreted very satisfied diners.

\section{c. Quadrant C (Low Priority)}

A quadrant that indicates services cape attributes are considered less important and the implementation by operators of mediocre, (Low Importance-Performance Low) can mean less satisfied visitors.

d. Quadrant D (Redundant)

A quadrant that indicates the attributes services cape considered less important visitors, but provided by the manager with good / redundant, (Low Importance-High Performance) can be interpreted very satisfied.

\section{CONCLUSION}

Based on the description and the measurement of visitor satisfaction levels with importance performance analysis method that has been stated above, it can be concluded in general, as much as $35.72 \%$ of visitors expressed great satisfaction with the services cape Attraction in Cave Ngalau Indah Payakumbuh.

\section{REFERENCE}

Goncalvez, Juliana Rocha. (2014). Importance-Performance Analysis: Revisiting a tool for the evaluation of clinical services. Journal Health. 6 (5), 285-291.

Kirk L. Wakefield, Jeffrey G. Blodgett.(1996) "The effect of the services cape on customers' behavioral intentions in leisure service settings", Journal of Services Marketing, $10(6), 45-61$

Martilla, John A. and John C James. (1977). "Importanceperformance analysis". Journal of Marketing (pre1986). 41 (Jan 1977), 77-79.

Martinez, C.L. (2003). Evaluation Report: Tools Cluster Networking Meeting \#1, Arizona, CenterPoint Institute, Inc.

Ruki, Ulli Aulia. (2011). Pengenalan Teori Servicescape dan Penerapannya Dalam Desain Interior. .Jurnal Humaniora. 2 (2), 1225-1235.

Zeithaml, V.A., Bitner, M.O., and Gremler, D.E. (2009). Services Marketing: Integrating Customer Focus Across the Firm. New York, Mcgraw-Hill/Irwin,. 